H. Matyi, P. Tamás, Miskolc, Hungary

\title{
DIGITAL TWIN TECHNOLOGY IN LOGISTICS LITERATURE REVIEW
}

\begin{abstract}
The digital twin has been released in a number of industries that include logistics as well, with the creation of new research areas. To find the research area, a complex literature analysis is required. At present, publications in scientific journals and publications on the Internet are more important than print-based literature. Because of this, you can get huge results with a single search. It is important that you can analyze these databases well. One method of this analysis is systematic literature review.
\end{abstract}

Keywords: digital twin; logistics; systematic literature review.

\section{INTRODUCTION}

Today, we are living in a digital revolution. In this way, digitalisation has transformed jobs, skills and the relationship between employer and employee. Most people live in a digital environment, so it's important to make full advantage of it. Digital transformations have many benefits, even in longer term. One of the most significant inventions of the 4th Industrial Revolution was the digital twin. This technology will be presented in the publication, such as its concept, version, and options for its application.

We analyze the research of the digital twin so far with a systematic literature review. This method is essential for analyzing published article's results. To analyze the success of the topic area, we create an annual chart of the publications published. For this, we define several keyword search methods as well as a combined search. The results are summarized to illustrate the results.

The purpose of the publication is to analyze them after a literature review. Highlighting the digital twin application in the field of logistics.

\section{MEAN FEATURES OF DIGITAL TWIN}

The digital twin is a virtual version of an object or system that spans its lifecycle, contains real-time data and uses simulation, machine learning. With digital twin the decision making is easier. The digital twin is the creation of a complex virtual model that is the twin sibling of a physical object. The digital twin is a vital tool for understanding not only the performance of the current product but also its future state [1].

The implementation of digital twin technology is possible with the Internet of Things as well as data analysis. As a first step, they create a mathematical model 
that properly simulates the original. Secondly, it has to be sure that the virtual model recieves feedback from the sensors that collect data from the real version. This allows the digital twin to show what happened to the original version in real time. The digital twin can be used in conjunction with a prototype to provide feedback on the product during development [5].

There are two versions of the digital twin. A digital twin prototype, which contains information that can be used to describe a real product. These can be the manufacturing process, 3D modell, bill of materials. The other version is the digital twin instance, which is a virtual product linked to a physically existing product. It contains the geometric data of the real object, 3D model, parts list, maintance results and information [2].

The application of the digital twin depends on which stage of the product lifecycle it models. They can be used in three main parts. These are product development, manufacturing and product design and the third one is the performance increasing. Using a digital twin, you can effectively design a new product. The twin allows you to virtually check the performance of the product, making visible how it affects the physical word. In this case, a virtual-physical connection is created that allows you to analyze how a product performs under different conditions. This reduces the need for multiplie prototypes. The use of digital twins can be analyzed by manufacturing and product design before production begin. If more digital twins are created from all production facilities, production can be further optimized. The digital twin created to increase performance generates a huge amount of data, analyzing this data from operating plants, help decision making [17].

\section{METHODS OF LITERATURE REVIEW}

Nowadays, publications in scientific journals and publications on the Internet are gaining prominence. Because of this, with one single research could give a huge amount of results. The disadvantage of this is you may encounter inconsistencies and information that may make the content unusable[10].

The systematic literature review is a high level, comprehensive study of a scientific methodology that summarizes and analyzes all the existing research findings on a given problem [6].

A systematic review of the scientific literature in a given field is improtant to indentify research questions and to justify future research in that field. This is a compley process, so it is important to know the right databases to conduct research [3].

\section{APPLIED METHODOLOGY}

We did the literature review using Systematic Literature Review (SLR) method. In practice, the usefulness of a research is mainly determined by its 
prevalence, not its print appearance. The SLR contains documentation of all methods performed [8].

Traditionally, literature reviews present research results in descriptive or narrative form. A good narrative presentation provides the reader with a comprehensive presentation of the various views of a discipline, including its key methodolodies and theoretical traditions. Denyer and Neely (2004) stated that reports about systematic reviews should include a section on the methodology used and provide an accurate description of the course study. In their view, this mainly necessary so that all decisions are taken in a transparent manner [4].

The aim of our work is to make a transparent scientific presentation of the topic, minimizing bias, through an extensive search for published studies, mainly in English and Hungarian. The goal of the publication is to create a reliable knowledge base.

SLR alone is already a scientific research, although it does not require a laboratory experiment, but involves preliminary design and application of the method [8].

Systematic literature review consists of the following steps: [10], [15]

1. Defining research questions (Who has done something so far? Who did the research or published it first?

2. Discover related literature, primarly using online databases.

3. Reduce results, select relevant publications and determine the main research direction by reading them (determining extra keywords, based on authors, date, etc)

4. Development of a method for processing and analyzing publications.

5. Formulation of major scientific breakthroughs and results.

6. Identifying a scientific gap or bottleneck.

Based on these steps, the following sections can be determined. First, we identify keywords related to digital twin technology. Then, we select databases in which publications can be searched in this regard. We will then gather the information for the relevant articles. [13].

The purpose of this publication is to present the research topic and literature sources using the Scopus, Web of Science and ScienceDirect databases.

\section{DATABASES}

We did our research in 3 databases. On Scopus, Web of Science and ScienceDirect. The keywords we searched for were the same in all three databases. When analyzing the literature, the first keywords were the followings, and their most important combinations:

- ,artificial intelligent”

- „digital twin”

- „digital twin technology” 
- „logistics”

- ,packaging”

- „transportation”

The search was conducted primarly with the words artificial intelligence, digital twin and digital twin technology. We first performed each field and then set a filtration search to title, abstract, and keywords. It is important to note that the analyzes were performed on 18th of November, 2021., since then more publications may have appeared. The time interval was narrowed from 2000 to 2021.

Table 1 summarizes the datas.

It is clear from the table that there is a growing number of publications in the subject area. It can be observed that most of the publications are in the Scopus database, then in the ScienceDirect and finally in the Web of Science database.

Subsequently, we also performed a combination search in the Scopus and then in the ScienceDirect database. The combined search in the Scopus database did not get any results. The combination keywords are:

- „digital twin” AND „logistics” OR ,digital twin technology” AND „logistics”

- „digital twin” AND „logistics” AND „packaging” OR „digital twin technology” AND „logistics” AND ,packaging”

- „digital twin” AND „logistics” AND „transportation” OR „digital twin technology” AND „logistics” AND ,transportation”

Than, we did a combine and filter research. The results is shown in a chart of the number of publications published per year.

The first search combination „digital twin” AND „logistics” OR „digital twin technology” AND ,logistics” we got 855 publication results at the end of 2021. Its annual analysis is shown in the following figure.

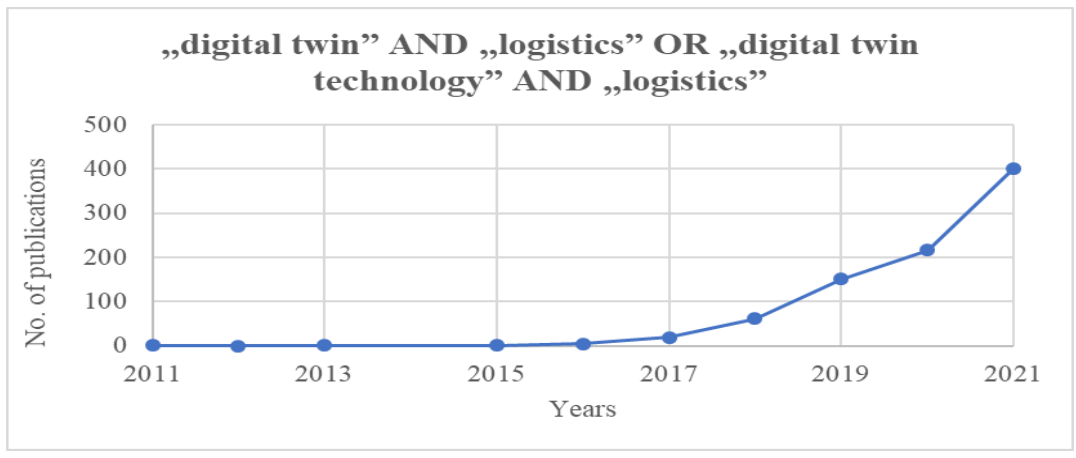

Figure 1 - ScienceDirect combined search results 1. (own editing) 


\section{ISSN 2078-7405 Cutting \& Tools in Technological System, 2021, Edition 95}

Table 1 - Searched datas (own editing)

\begin{tabular}{|c|c|c|c|c|}
\hline & Search fields & Searched key words & $2000-2021$ & 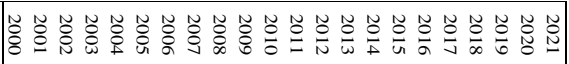 \\
\hline \multirow{6}{*}{$\begin{array}{l}\mathscr{8} \\
\frac{8}{0} \\
\frac{C}{n}\end{array}$} & all field & \multirow{2}{*}{ "Artificial Intelligent" } & 9577 & Uీ \\
\hline & title, abstract, key words & & 3364 & 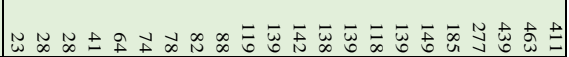 \\
\hline & all field & \multirow{2}{*}{ "Digital Twin" } & 11731 & 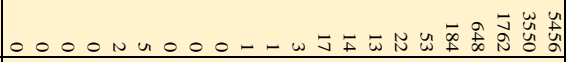 \\
\hline & title, abstract, key words & & 5384 & 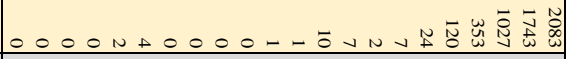 \\
\hline & all field & \multirow{2}{*}{ "Digital Twin Technology" } & 998 & $00000000000000000 \omega, \bar{N} \tilde{U}_{U}^{w}$ \\
\hline & title, abstract, key words & & 348 & $00000000000000000-\bar{\omega} \begin{array}{l}w_{0} \\
0\end{array}$ \\
\hline \multirow{6}{*}{$\begin{array}{l}\frac{5}{8} \\
8 \\
\frac{0}{6} \\
\frac{8}{9} \\
\frac{8}{8} \\
8\end{array}$} & all field & \multirow{2}{*}{ "Artificial Intelligent" } & 1398 & 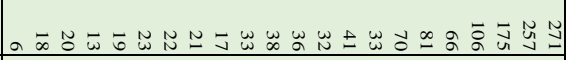 \\
\hline & title, abstract, key words & & 194 & 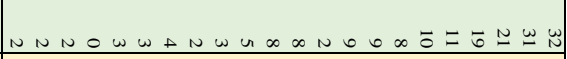 \\
\hline & all field & \multirow{2}{*}{ "Digital Twin" } & 1642 & 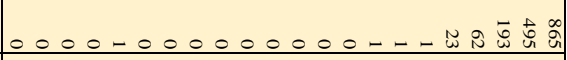 \\
\hline & title, abstract, key words & & 680 & 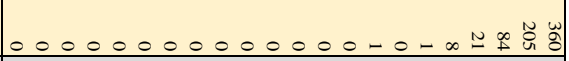 \\
\hline & all field & \multirow{2}{*}{ "Digital Twin Technology" } & & $000000000000000000+a w_{n}$ \\
\hline & title, abstract, key words & & 19 & $000000000000000000-n n_{0}$ \\
\hline \multirow{6}{*}{ 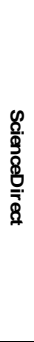 } & all field & \multirow{2}{*}{ "Artificial Intelligent" } & 4129 & 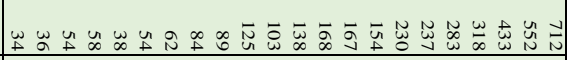 \\
\hline & title, abstract, key words & & 480 & 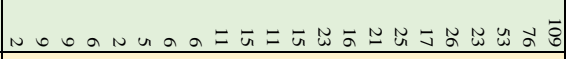 \\
\hline & all field & \multirow{2}{*}{ "Digital Twin" } & 3186 & 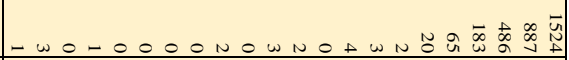 \\
\hline & title, abstract, key words & & 948 & $000-00000000000-n$ n \\
\hline & all field & \multirow{2}{*}{ "Digital Twin Technology" } & 280 & $0000000000000000 \ldots-v \infty u{ }^{n}$ \\
\hline & title, abstract, key words & & 58 & 00000000000000000 \\
\hline
\end{tabular}

On Figure 1. an increase can be seen in the numbers of publication. The second search combination is ,digital twin” AND ,logistics” AND ,packaging” OR ,digital twin technology” AND ,logistics” AND ,packaging”. The word „,packaging" related to my research topic was also included. There are 270 results for this. The results of the annual analysis are shown in Figure 2.

Another area of my research topic is transportation and the digital twin. So, we did the next combined search with these words ,digital twin” AND ,logistics” AND ,transportation” OR „digital twin technology” AND ,logistics” AND „,transportation”. This search combination resulted in 389 publications by 2021 . The results are shown in Figure 3. 


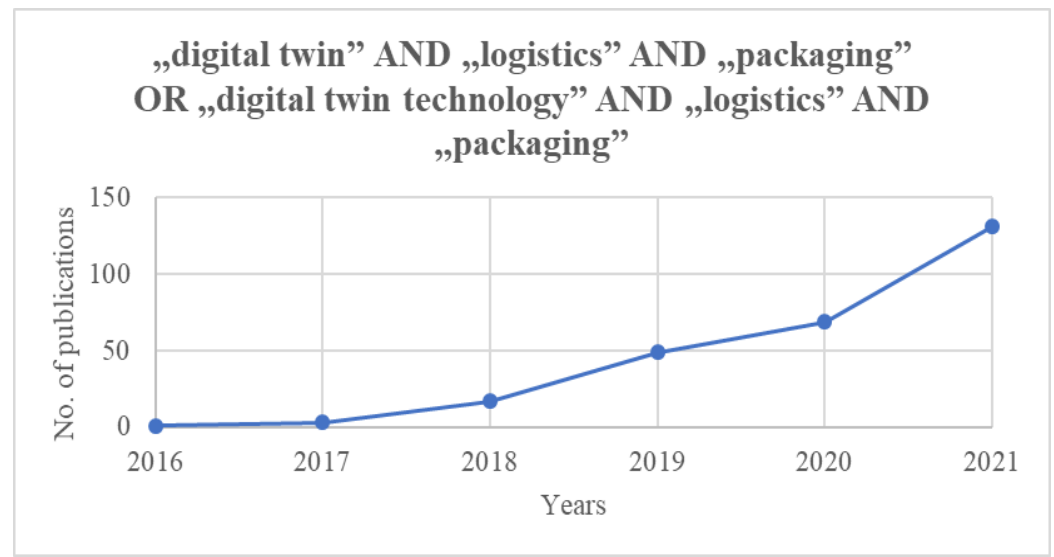

Figure 2 - ScienceDirect combined searched results 2. (own editing)

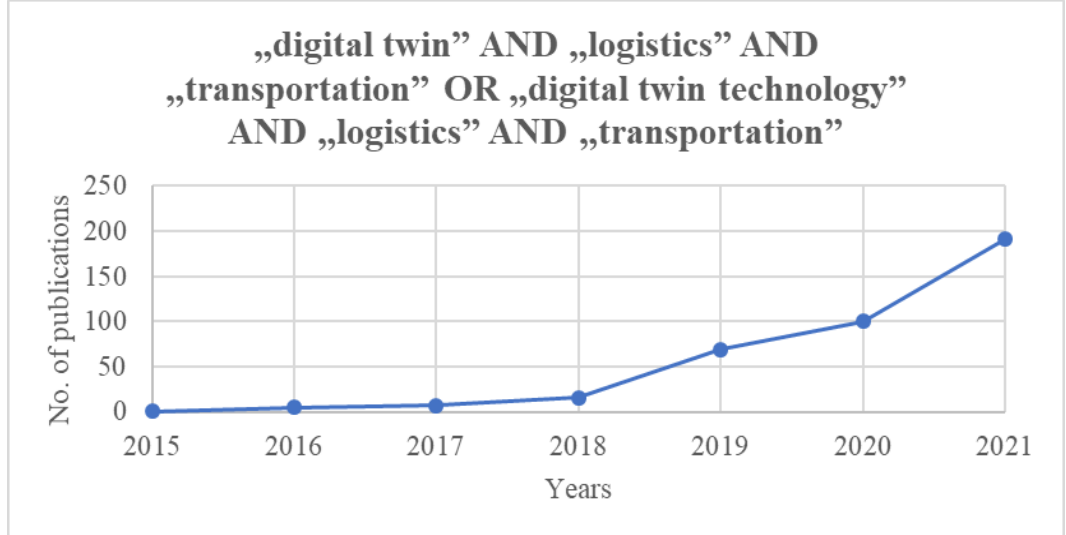

Figure 3 - ScienceDirect combined search results 3. (own editing)

\section{DIGITAL TWIN TECHNOLOGY IN THE LOGISTICS LITERATURE}

Digital twin technology has already appeared in many industries. With artificial intelligence and digital twin technology, an intellignt model can be created throughout the supply chain. Using virtual reality creates a better option that helps with various tasks such as vehicle loading [9], [12].

The operation and optimization of complex production and logistics enterprises is driven by actual data and simulation, and therefore requires a multi- 
faceted decision-making approach. Digital enterprise systems are complex, so the optimal solution may vary depending on the current situation. In decision making, the digital twin concept can be properly applied, covering the entire lifecycle of a device or process by forming a closed chain [11].

One of the main challenges in digital twin technology is making real-time decisions. The object must be constantly tracked and monitored. The Internet of Things also helps to make real-time decisions in logistics network by calculating, analyzing and optimizing real-time data. [7].

In our opinion, there is a huge potential for the application of digital twin technology in logistics. In our view, the two most important areas will be packaing development as well as transportation development.

\section{DIGITAL TWIN TECHNOLOGY TO IMPROVE PACKAGING}

Product and packaging data helps companies increase efficiency, such as optimizing packaging selection and container loading. Expensive and fraigle products, such as pharmaceuticals and electronic components are shipped with sensors that monitor the temperature, the spatial orientation of the packaging, shock and vibration. The latest version of this type of equipment includes sensors that continuously transmit data during cargo transportation [16].

One-used packaging has long been a threat to the environment, especially food packaging. By using the digital twin, errors can be easily filtered out by designing and then testing the packaging in digital space. Today, more and more companies are using biodegradable or reusable packaging. The digital twin can be used to monitor reusable container fleets and their damage [14].

\section{$\begin{array}{llll}\text { DIGITAL TWIN TECHNOLOGY TO IMPROVE } & \text { TO }\end{array}$ TRANSPORTATION}

Reusable containers are the standards for the logistics industry. These include reusable crates between standard ocean-going conatiners, aircraft, auto parts factories and containers for food and beverages to retail stores and end users. It is difficult to track such containers. Companies must not only control the movement of containers, but also check for the presence of any damage or contamination that could endanger future shipments. Using digital twin, collecting and analyzing all the data helps the decisions maker make the optimal decision. It also identifies problems such as rough handling of the container and lack of it. The next step in developing transportation by the digital twin is to include the contents of a package or container in the digital twin. The digital twin pair of the shipment will act as a repository for the data collected by sensors. [16]. 


\section{SUMMARY}

The article introduces the concept of the digital twin, digital technology, and the history of the development of technology.

During a review of the history of literature, articles on the publications published so far, with the search words artificial intelligent, digital twin and digital twin technology were summarized.

The digital twin has already achieved huge success in many areas, but has not yet reached its full potential in logistics. In this publication, we have presented the application of the digital twin in logistics.

\section{ACKNOWLEDGEMENT}

"The research work described in this article is the NTP-SZKOLL-20-0022 identifier "Focus'21-Focus on community by developing digital competencies" project, supported by the Ministry of Human Resources and Human Resources Support Manager."

References: 1. Armstrong M.M.: Cheat sheet: What is Digital Twin? (2020), https://www.ibm.com/blogs/internet-of-things/iot-cheat-sheet-digital-twin/ (Last opened: 2021.11.22.). 2. Bányai T., Bányainé Tóth Á., Illés B., Tamás P. (Hungarian book): Ipar 4.0 és logisztika, Miskolci Egyetem, Miskolc-Egyetemváros, ISBN 9789633581827, 2019. 3. Torres-Carrión és társai: Methodology for systematic literature review applied to engineering and education (2018), 2018 IEEE Global Engineering Education Conference (EDUCON), https://doi.org/10.1109/EDUCON.2018.8363388. 4. Denyer, D., \& Neely, A. (2004). Introduction to special issue: Innovation and productivity performance in the UK. International Journal of Management Reviews, 5-6(3-4), 131-135.doi:10.1111/j.1460-8545.2004.00100.x 5. What is Digital Twin Technology and how does it work? https://www.twi-global.com/technical-knowledge/faqs/what-isdigital-twin\#HowDoesDigitalTwinTechnologyWork (Last opened: 2021.11.22.). 6. Walsh D., Downe S. (2005) Meta-synthesis method for qualitative research: a literature review, National Library of Medicine https://doi.org/10.1111/j.1365-2648.2005.03380.x. 7. Greif T., Stein N., Flath. M. C., (2020): Peeking into the void: Digital twins for construction site logistics. 8. Ginieis M., Sánchez-Rebull M.-V., CampaPlanas F. (2011): The academic journal literature on air transport: Analysis using systematic literature review methodology, https://doi.org/10.1016/j.jairtraman.2011.12.005. 9. Jörn Petereit, Digital twins and Artificial Intelligence in logistics, https://www.cloudflight.io/expert-views/digital-twins-andartificial-intelligence-in-logistics-44867/ (Last opened: 2021. 11. 22.). 10. Kamarási V.; Mogyorósy G. (2015): Szisztematikus irodalmi áttekintések módszertana és jelentősége. Segítség a diagnosztikus és terápiás döntésekhez, Orvosi Hetilap 156 (38), pp. 1523-1531. 11. Kuehn W., (2018)(Hungarian publication), Digital twins for decision making in complex production and logistic enterprises, htto://doi.org/10.2495/DNE-V13-N3-260-271. 12. Mobinius Editor (2020). Digital Twins Technology in Logistics 2021: In-Depth Guide, https://www.mobinius.com/blogs/digital-twin-technology-inlogistics (Last opened: 2021. 11. 22.). 13. Moustaghfir K. (2008): The dynamics of knowledge assets and their link with firm performance, Measuring Business Excellent, ISSN: 1368-3047. 14. 5 Ways Digital Twinning will revolutionize Logistics, https://lot.dhl.com/5-ways-digital-twinning-willrevolutionize-logistics/ (Last opened: 2021. 11. 22.). 15. Szentesi Sz. (2021) Ellátási láncok optimális kialakításának lehetőségei bizományosan értékesítő étrendkiegészítőket gyártó vállalatnál, Phd értekezés (Hungarian publication). 16. Schislyaeva, Rostislavovna E., Kovalenko, Alexandrovich E., (2021), Academy of Strategic Management Journal, suppl. Special Issue 2., Arden vol.20. (1-17), e- 
ISSN: 19396104. 17. Siemens: Digital Twin, https://www.plm.automation.siemens.com/global/en/ourstory/glossary/digital-twin/24465 (Last opened: 2021.11.22.).

\author{
Генрієтт Матій, Петер Тамаш, Мішкольц, Угорщина
}

\title{
ТЕХНОЛОГІЯ «DIGITAL TWIN» (ЦИФРОВОГО ПРОТОТИПУ) У ЛОГІСТИЦІ В ЛІТЕРАТУРНОМУ ОГЛЯДІ
}

\begin{abstract}
Анотація. Цифровий двійник був випущений у низці галузей, включаючи логістику, зі створенням нових галузей досліджень. Для визначення галузі дослідження необхідно провести комплексний аналіз літератури. Більшість людей живуть у цифровому середовищі, тому важливо повною мірою використати його переваги. Цифрові перетворення мають багато переваг навіть у довгостроковій перспективі. Одним із найзначніших винаходів 4-ї промислової революиії став цифровий двійник. Ця технологія буде представлена в публікації, включаючи ії конщепцію, версію та варіанти ї̈ застосування. Ми аналізуємо дослідження цифрового двійника зараз із системним оглядом літератури. Цей метод є важливим для аналізу результатів опублікованої статті. Щоб проаналізувати успішність тематичної галузі, ми складаємо річний графік опублікованих публікацій. I тому ми визначаємо кілька методів пошуку за ключовими словами, $i$ навіть комбінований пошук. Мета нашої роботи - зробити прозору наукову презентацію теми, мінімізуючи упередженість, за допомогою цирокого пошуку опублікованих досліджень, переважно англійською мовою. Мета публікації - створити надійну базу знань. Ми провели дослідження у трьох базах даних. У Scopus, Web of Science ma ScienceDirect. Ключові слова, які ми шукали, були однаковими у всіх трьох базах даних. Пошук проводився в основному за словами штучний інтелект, цчифровий двійник та технологія циифрового двійника. Робота та оптимізація складних виробничих та логістичних підприємств визначається фактичними даними та моделюванням $i$, отже, потребує багатогранного підходу до прийняття рімень. Цифрові корпоративні системи складні, тому оптимальне рімення може змінюватись в залежності від поточної ситуачії. При прийнятті рішень концепція циифрового двійника може бути належним чином застосована, охоплюючи весь життєвий цикл пристрою або процесу утворюючи замкнутий ланцюжок. На наш погляд існує величезний потенціал для застосування технології цифрових двійників у логістиці. На наш погляд, двома найважливішими напрямками будуть розвиток упаковки та розвиток транспорту.
\end{abstract}

Ключові слова: ичировий двійник; логістика; системний огляд літератури. 